\title{
Influence of preliminary treatments on structural properties of casein micelles affecting the rennetability
}

\author{
B Lieske
}

AN-Institut der FH Anhalt, Dr Zinnweg 18, D16225 Eberswalde, Germany

\begin{abstract}
Summary - Different reconstituted skimmed milk powders, as well as defatted pasteurized and raw milk, were used to probe the effects of preheating conditions on rennetability and molecular availability of casein to coagulate and to form a curd. The experiments for following coagulation and gel formation were carried out using the formagraph at $\mathrm{pH} 6.4,35^{\circ} \mathrm{C}$, and $3.8 \%$ total protein. Two new approaches to estimate the surface protein hydrophobicity (SPH) and to quantify the glycosylated and non-glycosylated caseinomacropeptide (CMP) were used to study the molecular state of casein micelles during the primary and secondary phases of renneting. The latter method was supported by ion-exchange fast-protein liquid chromatography (FPLC) using Mono-Q and Mono-S columns. Results with raw milk showed that the SPH of native micellar casein is about eight times higher than that of the individual casein components. In processed milks, the range of maximum SPH decreased as the severity of preheating increased. It was found that a high SPH is correlated with an optimum micellar structure. The latter is progressively lost by association of denatured $\beta$-lactoglobulin $(\beta-\mathrm{Lg})$ on the micellar surface, especially with the outer part of non-glycosylated $\kappa$-casein $(\kappa-\mathrm{Cn})$. The extent of association is related to the severity of preliminary milk treatment, which may be measured by a reduced liberation of non-glycosylated CMP.
\end{abstract}

heating / proteolysis / kinetic / caseinomacropeptide / hydrophobicity

Résumé - Influence de prétraitements sur la structure des micelles de caséine et son aptitude à la coagulation. Différentes poudres de lait écrémé reconstitué, ainsi que des laits dégraissé pasteurisé et cru, ont été utilisés pour tester l'effet des conditions de préchauffage sur l'aptitude à la coagulation et sur la disponibilité moléculaire de la caséine pour coaguler et pour former un caillé. Les essais pour suivre la coagulation et la formation du gel ont été réalisés à l'aide du Formagraph à $\mathrm{pH} 6,3,35^{\circ} \mathrm{C}$ et $3,8 \%$ de protéines totales. Deux nouvelles approches, l'une pour estimer l'hy-

Oral communication at the IDF Symposium 'Ripening and Quality of Cheeses', Besançon, France, February $26-28,1996$. 
drophobicité de surface protéique et l'autre pour quantifier le caséinomacropeptide glycosylé et non glycosylé, ont été utilisées pour étudier la forme moléculaire des micelles de caséine au cours des phases primaire et secondaire de la coagulation. La seconde méthode reposait sur l'emploi de la chromatographie d'échange d'ions FPLC utilisant des colonnes Mono-Q et Mono-S. Les résultats obtenus sur lait cru montrent que l'hydrophobicité de surface de la caséine micellaire native est environ huit fois plus élevée que celle des caséines individuelles. Dans les laits traités, le niveau maximal d'hydrophobicité de surface diminuait lorsque la sévérité du préchauffage augmentait. Il a été montré qu'une hydrophobicité de surface élevée est corrélée avec une structure micellaire optimale. Celle-ci est progressivement perdue par association de $\beta$-lactoglobuline dénaturée sur la surface micellaire, spécialement avec la partie externe de la caséine $\kappa$ non glycosylée. L'étendue de l'association est fonction de la sévérité du traitement préliminaire du lait, ce qui peut être mesuré par une libération réduite du caséinomacropeptide non glycosylé.

\section{chauffage / protéolyse / cinétique / caséinomacropeptide / hydrophobicité}

\section{INTRODUCTION}

The effect of heat on milk proteins is an important processing parameter during production of a wide variety of dairy foods. Heating leads to an immediate reduction in the numbers of detrimental, but also of useful microorganisms, and the storage life of milk is improved significantly provided that appropriate measures are taken to prevent post-treatment contamination. However, improving the microbiological quality by thermal treatments may impair the rennetability of milk dependent on the extent of preliminary heating. Mild heat treatments, like thermization (64-68 ${ }^{\circ} \mathrm{C}$ for $10 \mathrm{~s}$ ), have been reported to adequately preserve the renneting properties of raw milk. More severe procedures cause irreversible molecular changes which are related mainly to complex formation via sulphhydryl-disulphide interchange and hydrophobic interactions between $\beta$-lactoglobulin $(\beta$ - $\mathrm{Lg})$ and $\kappa$-casein ( $\kappa-\mathrm{Cn}$ ) (Zittle et al, 1962; Sawyer, 1969; Haque and Kinsella, 1988). It seems to be the most important factor affecting the rennet coagulability of heated milk (Van Hooydonk et al, 1987; Dalgleish, 1990).

The rennet coagulation time ( $R C T$ ) (Wheelock and Kirk, 1974; Marshall, 1986), as well as gel firmness (Van Hooydonk et al, 1987; McMahon et al, 1993), of milk are impaired by the severity heat treatments. Nevertheless, it is still speculative whether the increased RCT is caused by a decreased enzymic availability or by hindered aggregation of the modified micelles, or both. The strength of rennet gels is also adversely affected in heated milk (Singh et al, 1988; McMahon et al, 1993), presumably due to disruption of the continuity of the gel network by denatured whey proteins on the surface of casein micelles (Lucey et al, 1994).

This work was aimed at studying the molecular-structural changes leading to impaired rennetability of casein micelles via two new approaches which were developed in our laboratory: first, a method to estimate the surface hydrophobicity (SHP) of proteins; and secondly, a spectrophotometric assay to quantitatively differentiate between total caseinomacropeptide (CMP) and its glycosylated form (GMP) released during renneting of casein. The difference between CMP and GMP represents the carbohydrate-free macropeptide.

\section{MATERIALS AND METHODS}

\section{Milks}

The experiments were performed on five milk substrates which were graded according to the severity of preliminary heating, ie: fresh raw milk from a local dairy farm; skimmed twice at $3000 \mathrm{~g}$ and maintained at $15^{\circ} \mathrm{C}$ for $30 \mathrm{~min}$; fresh pasteurized skim-milk ( $74^{\circ} \mathrm{C}$ for $20 \mathrm{~s}$ ); recon- 
stituted low-heat skim-milk powder (NILAC, NIZO, Ede, The Netherlands); reconstituted medium-heat nonfat dry milk (sample NDM-B; Humana, Herford, Germany); reconstituted highheat nonfat dry milk (sample NDM-A; Humana, Herford, Germany).

\section{Reconstitution of milk powders}

Milk was reconstituted by making up $11 \mathrm{~g}$ powder to $100 \mathrm{~g}$ using $5 \mathrm{mmol} \mathrm{L}^{-1} \mathrm{CaCl}_{2}$. To prevent bacterial growth, $0.02 \% \mathrm{NaN}_{3}$ was added. After stirring for $30 \mathrm{~min}$ at $30^{\circ} \mathrm{C}$, the temperature was raised to $40^{\circ} \mathrm{C}$ and stirring was repeated for a further $30 \mathrm{~min}$. Then the reconstituted milk was immediately cooled to $5^{\circ} \mathrm{C}$, and before overnight storage at this temperature the $\mathrm{pH}$ was adjusted to $\mathrm{pH} 6.4$ using glucono- $\delta$-lactone (Merck, Darmstadt, Germany). The substrate was prepared for renneting by stirring at $30^{\circ} \mathrm{C}$ for 30 $\mathrm{min}$. The protein content was estimated using the Kjeldahl method for raw milk, pasteurized milk, low-heat, medium-heat, and high-heat reconstituted skim-milk to be $3.61,3.62,3.78$, 3.73 and $3.73 \%$, respectively. The applied enzyme was pure natural calf chymosin (P99), a gift from Chr. Hansen Laboratory (Lübeck, Germany). For all experiments, a constant enzyme: substrate (E:S) ratio of 1:7000 was used.

\section{Formagraph}

Temperature and $\mathrm{pH}$ of renneting were set at $35^{\circ} \mathrm{C}$ and $6.4 \mathrm{RCT}$; gel firming rate $\left(\mathrm{K}_{20}\right)$ and curd firmness $\left(\mathrm{A}_{30}\right)$ were determined according to the Formagraph ${ }^{\circledR}$ users' manual (Foss Electric, Denmark).

\section{Surface hydrophobicity}

The protein SHP was determined as described by Lieske and Konrad (1995) based on specific binding of the non-ionic detergent Tween 80 on hydrophobic areas of protein molecules, which was quantified by the BIO-RAD protein assay.

\section{Caseinomacropeptide determination}

Qualitative and quantitative differentiation between CMP and GMP in trichloroacetic acid (TCA) filtrates was carried out according to the procedure of Lieske and Konrad (1996). The assay is based on a spectrophotometric determination of recovery of CMP at different TCA concentrations. Whole CMP may be solubilized at $6 \%$ TCA in the presence of $\mathrm{Na}_{2} \mathrm{SO}_{4}$, while GMP is recovered in $12 \%$ TCA.

\section{Chromatographic separation}

Chromatographic separation of CMP and $\beta-\mathrm{Lg}$ were carried out by fast protein liquid chromatography (FPLC) (Pharmacia Biotech, Freiburg, Germany) fitted with a Mono-S column (Léonil and Mollé, 1991) or a Mono-Q column (Andrews et al, 1985), respectively.

\section{RESULTS AND DISCUSSION}

\section{Effect of heating on renneting properties}

Results obtained using the Formagraph ${ }^{\circledR}$ are summarized in figure 1a-c. On comparing the different thermal regimes, it is clear that pasteurization is the most gentle method. Furthermore, low-heat drying with the low-heat skimmilk powder caused some visible losses in all three Formagraph ${ }^{\circledR}$ criteria. In the presence of $5 \mathrm{mmol} \mathrm{L}^{-1} \mathrm{CaCl}_{2}$, these deficiencies were restored to the level of pasteurized milk, which was not the case for medium-heat (NDM-B) or high-heat skim-milk powder (NDM-A). The impaired rennetability of both substrates was not attributed simply to a deficiency in $\mathrm{Ca}^{2+}$ but to irreversible molecular changes, which were caused by complex formation between $\beta$ - Lg and micellar $\kappa-\mathrm{Cn}$. This was visualized by chromatographic separation of free $\beta-\mathrm{Lg}$, as shown in figure 2 . As indicated, $\beta$ - $\mathrm{Lg}$ was definitely involved in molecular changes with a preference for the $\beta-\mathrm{Lg} B$ variant, suggesting that the minor changes in the sequence of these proteins may 


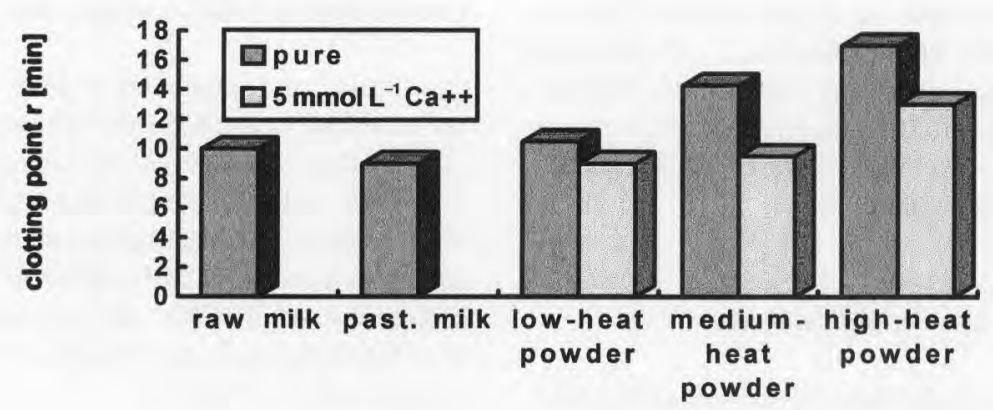

b)

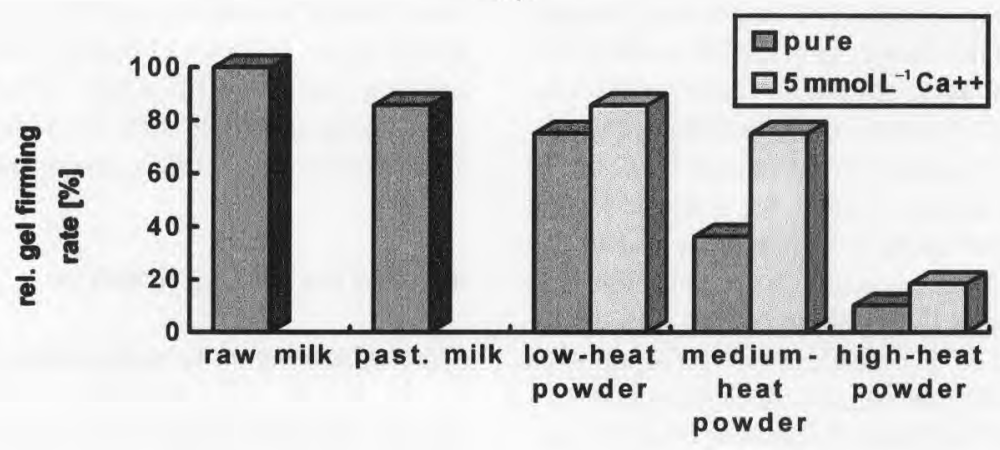

c)

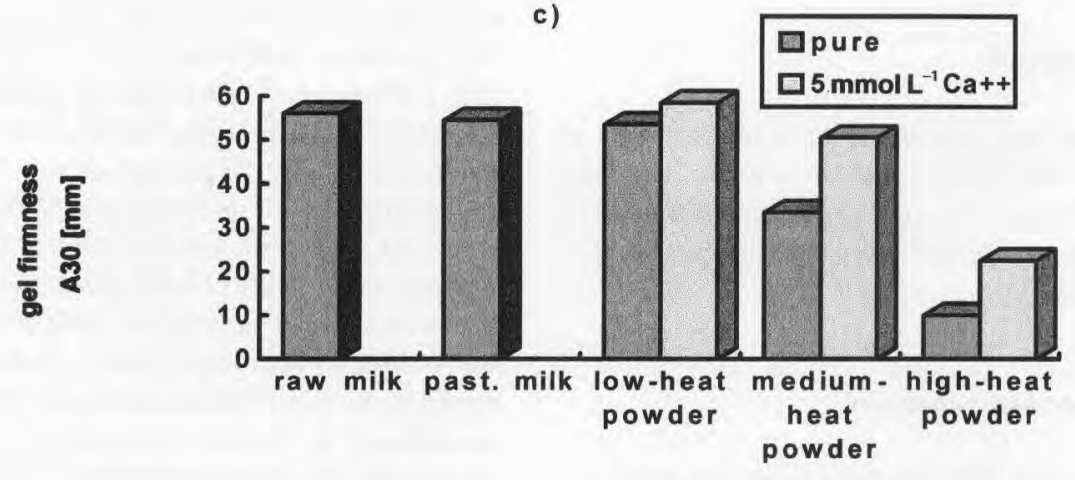

Fig 1. Effect of heating on the rennetability of pasteurized milk and three reconstituted milk substrates compared to raw milk followed by use of the Formagraph ${ }^{\circledR}\left(\mathrm{RCT}, \mathrm{K}_{20}, \mathrm{~A}_{30}\right)$.

Effet du chauffage sur l'aptitude à la coagulation du lait pasteurisé et de trois laits reconstitués comparés au lait cru, suivie à l'aide du Formagraph. 
be responsible for an increased lability of $\beta-\mathrm{Lg}$ B to heating (Manderson et al, 1995).

Complex formation between $\beta-\mathrm{Lg}$ and $\kappa-\mathrm{Cn}$ may drastically impair gel formation and curd firmness, which has been verified by turbidimetric measurements. The latter method failed with both substrates, NDM-B and NDM-A, because monitoring the turbidity of undiluted milk showed no increase of turbidity in the presence of chymosin. The underlying molecularstructural changes interfere with the good rennetability of micellar casein, which will be elucidated in the following section.

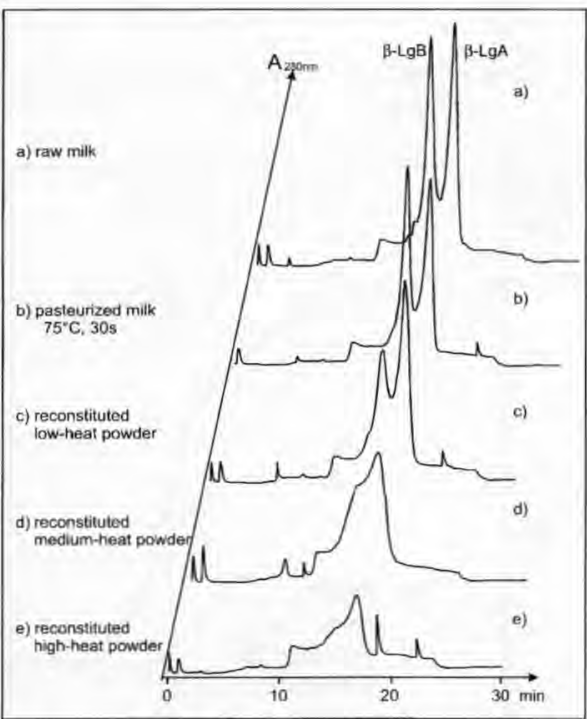

Fig 2. Effect of severity of thermal pretreatments on the solubility of $\beta$ - Lg in $2 \%$ TCA (FPLC separation on Mono-Q. $20 \mathrm{mmol} \mathrm{L}^{-1}$ Tris- $\mathrm{HCl}$, pH 7.0 using a $0-0.35 \mathrm{~mol} \mathrm{~L}^{-1} \mathrm{NaCl}$ gradient, $1 \mathrm{~mL} \mathrm{~min}^{-1}, 280 \mathrm{~nm}$, $0.1 \mathrm{mg}$ protein).

Effet de l'intensité du préchauffage sur la solubilité de la $\beta$-lactoglobuline dans le TCA 2 \% (séparation par chromatographie FPLC sur colonne Mono-Q, $20 \mathrm{mmol} \mathrm{L} L^{-1}$ Tris- $\mathrm{HCl}, \mathrm{pH} 7,0$ en utilisant un gradient de $\mathrm{NaCl}$ de $0-0,35 \mathrm{~mol} \mathrm{~L} \mathrm{~L}^{-1}, 1 \mathrm{~mL} \mathrm{~min}^{-1}, 280 \mathrm{~nm}$, $0,1 \mathrm{mg}$ de protéine).

\section{Effect of heating on surface hydrophobicity (SHP)}

In an earlier work, the SHP of the three main individual caseins, $\alpha_{s^{-}}, \beta$ - and $\kappa$-Cn was found to be $\mathrm{pH}$-dependent and was estimated to be 8-10\% SHP at pH 7.0 (Lieske and Konrad, 1995). Free caseins are detectable in fresh milk at low concentration. Assembly to casein micelles is preferred, and is also a prerequisite for enzymic coagulation and curd formation at natural $\mathrm{pH}$ of milk. The micellar assembly is characterized by an exceptionally high hydrophobic potential which may be about eight to ten times higher than that of the individual caseins (fig $3 a-c$ ).

To our knowledge, no other method apart from that used here reflects the extremely hydrophobic nature of casein resulting from the micellar assembly aided by a selected ionic environment. It seems reasonable to assume that interactions between micellar casein and chymosin must be hydrophobically driven. The corresponding SHP of pure chymosin was estimated to be $30-33 \%$ for the $\mathrm{pH}$ range $5.7-7.0$.

As shown in figure 3, micellar SHP was very sensitive to $\mathrm{pH}$ changes. Decreases in SHP were detected first at $\mathrm{pH}>6.25$, which is in the technologically significant $\mathrm{pH}$ range for the practical renneting process. SHP was affected not only by thermal processing but also by anything which altered the ionic environment of casein micelles and ageing due to proteolysis, which is seen with NDM-B (see also the respective CMP; fig 4d).

Without preliminary heating, micellar structures showed a high tendency to loosen at $\mathrm{pH}$ 6.7-6.8, at which level $\kappa-C n$ is less effective in stabilizing the micelles due to reduced $\mathrm{Ca}^{2+}$ activity and an increased interaction between $\mathrm{Ca}^{2+}$ and the individual caseins. A similar effect was described by Singh and Fox (1985) on heating milk at $\mathrm{pH}>6.9$. The micellar SHP decreased to about $30 \%$, an order of magnitude which is identical with to that for high quality commercial rennet casein (Lieske and Konrad, 1995). However, good rennetability of milk closely corre- 

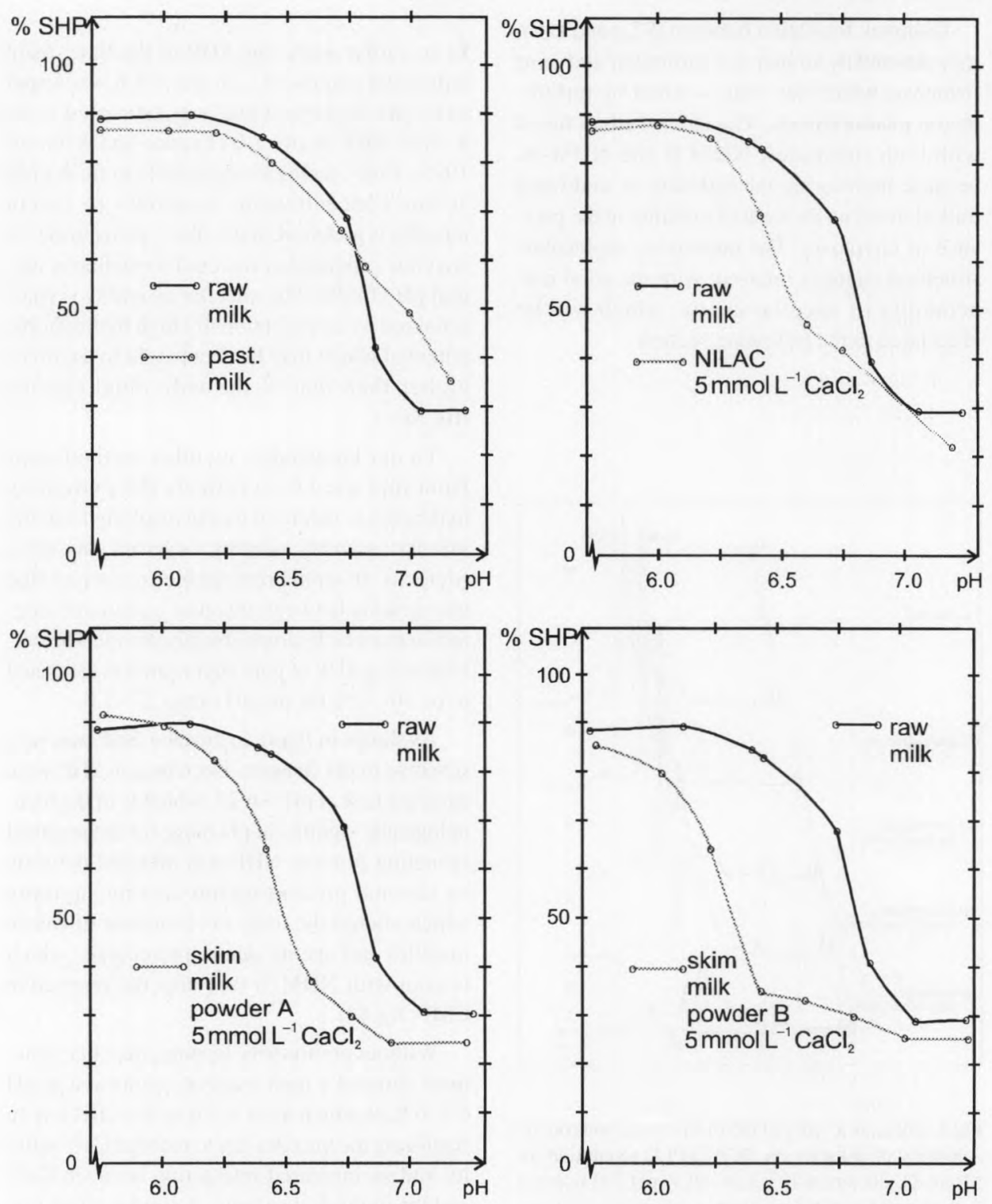

Fig 3. Effect of heating on the surface hydrophobicity (SHP) of micellar casein in pasteurized milk and three reconstituted milk substrates compared to the SHP of raw milk.

Effet du chauffage sur l'hydrophobicité de surface de la caséine micellaire dans le lait pasteurisé et les trois laits reconstitués comparée à celle du lait cru. 
sponds with a high SHP, which is developed in the technologically feasible $\mathrm{pH}$-range and vice versa (figs 1,3). The effects of $\mathrm{Ca}^{2+}$ and those of a combined acidification and neutralization (Lucey et al, 1994) on SHP and the respective micellar composition are under investigation.

\section{Effects of heating on macropeptide release}

Figure 4 shows the chromatographic profiles of CMP released from the five milk substrates during renneting. The relative concentration compared with raw milk indicates the enzymatic availability of the chymosin-sensitive bond in $\kappa-\mathrm{Cn}$. The macropeptide quantitative data were

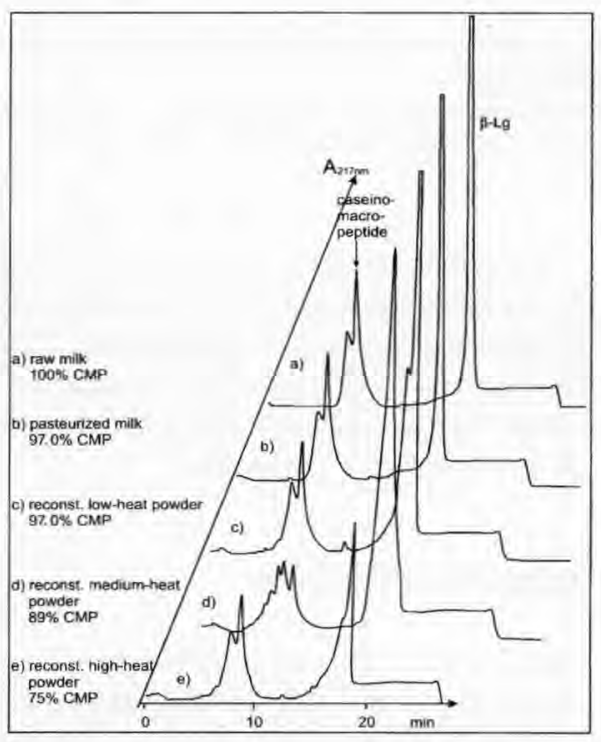

Fig 4. Effect of the thermal pretreatments on enzymatic availability of the chymosin-sensitive peptide bond in $\kappa$-casein visualized by FPLC using a Mono-Q column $\left(20 \mathrm{mmol} \mathrm{L}^{-1} \mathrm{KCl} / \mathrm{HCl}\right.$ buffer, $\mathrm{pH} 2.0$, biphasic $\mathrm{NaCl}$ gradient $0-1.5 \mathrm{~mol} \mathrm{~L}^{-1}, 1 \mathrm{~mL} \mathrm{~min}^{-1}$, CMP released from $1.275 \mathrm{mg}$ casein).

Effet du préchauffage sur l'hydrolyse enzymatique de la liaison peptidique sensible à la chymosine de la caséine $\kappa$, visualisée par chromatographie FPLC sur colonne Mono-Q $\left(20 \mathrm{mmol} \mathrm{L}^{-1}\right.$ tampon $\mathrm{KCl} / \mathrm{HCl}, \mathrm{pH} \mathrm{2,0}$, gradient biphasique de $\mathrm{NaCl}$ $0-1.5 \mathrm{~mol} \mathrm{~L} \mathrm{~L}^{-1}, 1 \mathrm{~mL} \mathrm{~min}^{-1}$, caséinomacropeptide libéré de 1,275 mg de caséine. obtained using a new spectrophotometric assay which was found to be superior to chromatographic separation considering the selectivity between the glycosylated and non-glycosylated forms as well as the quantitative reproducibility, which was confirmed in figure 5 .

To characterize the rennetability of the milk substrates studied by following the enzymatic destruction of micellar $\mathrm{K}-\mathrm{Cn}$, the release of total macropeptide (upper line) as well as of GMP (lower curve) was estimated versus time. The enzymatic reaction was extended twice as much as usual to record all changes in the carbohydrate-free macropeptide, which is an arithmetical calculation between CMP and GMP. The course of CMP release showed a typical shoulder which occurs prior to the visual clotting point, indicated by an arrow. As can be seen, enzymatic kinetics followed a course favouring a step function approach, whereas the release of GMP may be described by an integrated form of the Michaelis-Menten equation. In any case, more than $90 \%$ of GMP were released at the visual clotting point, which is in agreement with the results of Chaplin and Green (1980) who found using electrophoresis that para-casein and GMP reached an almost maximum concentration at the clotting point at $\mathrm{pH} 6.6$. The maximum concentration of GMP was estimated in the same order of magnitude for all milk substrates studied here independent of preliminary heatings (fig 5).

Considering the subject of this article, heating of milk proteins leads to formation of covalent bonds between $\kappa-\mathrm{Cn}$ and $\beta-\mathrm{Lg}$ with preference to $\beta$ - $\mathrm{Lg} B$. In this case, less nonglycosylated macropeptide is released and less $\beta-\mathrm{Lg}$ is detectable in the native form. Therefore, the quotient of GMP and CMP increases with the severity of thermal treatments. Turbidity studies supported by Formagraph ${ }^{\circledR}$ results confirmed that the release of non-glycosylated macropeptide was related to the rate of gel firming $\left(\mathrm{K}_{20}\right)$ as well as gel firmness $\left(\mathrm{A}_{30}\right)$, and its blocking by whey protein impaired the rennetability of milk with the increasing severity of heat processing. 


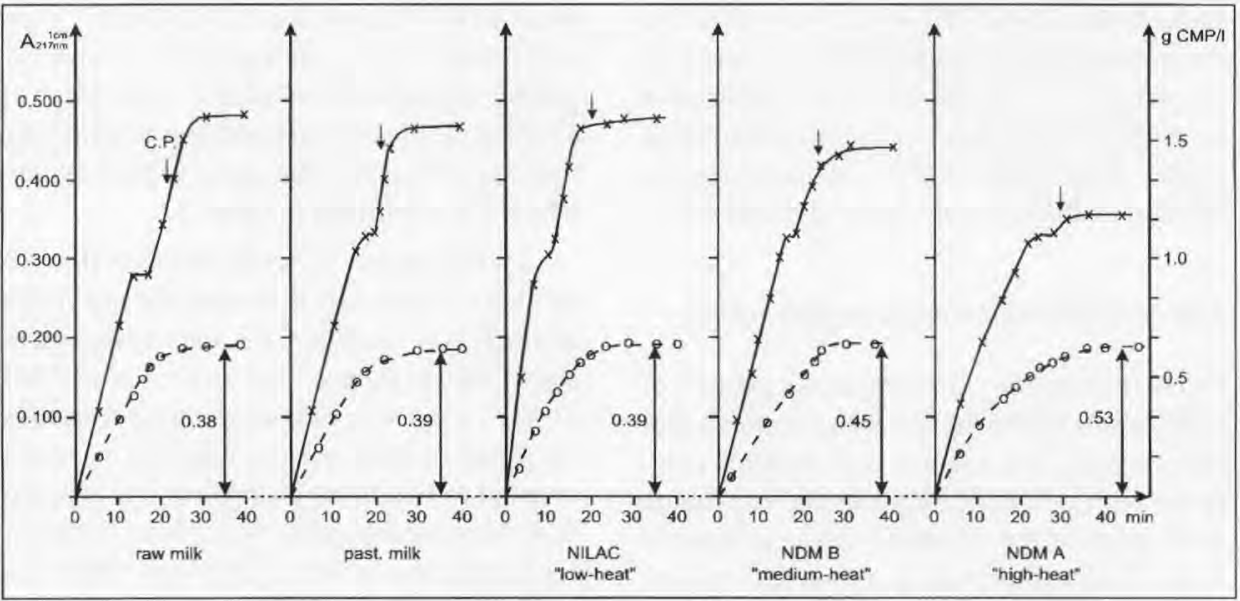

Fig 5. Influence of severity of milk heating on the release of caseinomacropeptide (CMP) $(x-x)$ and its glycosylated derivates (GMP) $\left(\mathrm{O}_{-}-\mathrm{O}\right)$ during renneting of micellar casein.

Influence de la sévérité du chauffage du lait sur la libération de caséinomacropeptide (CMP) $(\times-x)$ et de sa forme glycosylée $(G M P)\left(O_{-}-O\right)$ au cours de la coagulation de la caséine micellaire.

The target of most theoretical explorations into renneting has been to derive, as well as possible, an expression for the clotting time and to show a physical-chemical basis for the Holter or Payens equation (Payens, 1977). As seen in figure 5 , there are serious indications that the liberation of the non-glycosylated macropeptide follows the temporal course of aggregation, which seems to be dependent on the availability of reactive particles in the micellar kernel. Using raw milk at three $\mathrm{pH}$ levels, Lieske and Konrad (1996) documented these data.

The kinetic parameters obtained here were less suitable for deriving any mathematical expressions because the substrates used had a number of limitations, eg: i) all substrates were of different origin and micellar conditions of milks as well as the rate of casein to total protein were not treated equivalently; and ii) substrates were of different age, eg, 'medium-heat' milk powder had been stored for about 9 months prior to investigations. Prolonged storage caused impaired surface hydrophobicity (fig 4) and a scattered macropeptide peak, as indicated by chromatography on Mono-Q column (fig 3 ).
From this study it is obvious that several details need further refinement. Nevertheless, the applied set of criteria for thermal effects on the rennetability of casein micelles will contribute to a better understanding of the physicochemical parameters involved.

\section{ACKNOWLEDGMENT}

This work was supported by the Scientists Integration Programme (WIP) for East German Scientists of the Federal Government of Germany and of the Federal State Sachsen-Anhalt.

\section{REFERENCES}

Andrews AT, Taylor MD, Owen AJ (1985) Rapid analysis of bovine milk proteins by fast protein liquid chromatography. J Chromatogr 348, 177-185

Chaplin B, Green ML (1980) Determination of the proportion of $\mathrm{K}$-casein hydrolysed by rennet on coagulation of skim-milk. J Dairy Res 47 , 351-358 
Dalgleish DG (1990) The effect of denaturation of $\beta$-lactoglobulin on renneting - a quantitative study. Milchwissenschaft 45, 491-494

Haque Z, Kinsella JE (1988) Interaction between heated $\kappa$-casein and $\beta$-lactoglobulin: predominance of hydrophobic interactions in the initial stage of complex formation. J Dairy Res 55, 67-80

Léonil J, Mollé D (1991) A method for determination of macropeptide by cation-exchange fast protein liquid chromatography and its use for following the action of chymosin in milk. $J$ Dairy Res 58 , 321-328

Lieske B, Konrad G (1995) Determination of surface hydrophobicity of milk proteins. Comparison between a new detergent binding method and hydrophobic interaction-FPLC. Milchwissenschaft 50, 10-13

Lieske B, Konrad G (1996) A new method to estimate caseinomacropeptide and glycomacropeptide from trichloro-acetic acid filtrates. Milchwissenschaft $51,431-435$

Lucey JA, Gorry C, Fox PF (1994) Methods for Improving the Rennet Coagulation Properties of Heated Milk. Bull No 9402. Int Dairy Fed, Brussels, 448-456

Mc Mahon DJ, Yousif BH, Kalab M (1993) Effect of whey protein denaturation on structure of casein micelles and their rennetability after ultra-high temperature processing of milk with or without ultrafiltration. Int Dairy J 3, 239-256

Manderson AB, Manderson CG, Hardman MJ, Creamer LK (1995) Thermal denaturation of bovine $\beta$-lactoglobulin. J Dairy Sci 78, suppl 1, D 113
Marshall RJ (1986) Increasing cheese yields by heat treatment of milk. J Dairy Res 53, 313-322

Payens TAJ (1977) On enzymic clotting processes. II. The colloidal instability of chymosin-treated casein micelles. Biophys Chem 6, 263-270

Sawyer WH, Coulter ST, Jenness R (1963) Role of sulfhydryl groups in the interaction of $\kappa$-casein and $\beta$-lactoglobulin. J Dairy Sci 46, 564-565

Sawyer WH (1969) Complex between $\beta$-lactoglobulin and $\kappa$-casein. A review. J Dairy Sci 52, 1347-1355

Singh, H, Fox PF (1985) Heat stability of milk: pHdependent dissociation of micellar $\kappa$-casein on heating milk at ultra-high temperatures. $J$ Dairy Res 52, 529-538

Singh H, Shalabi SI, Fox PF, Flynn A, Barry A (1988) Rennet coagulation of heated milk. Influence of $\mathrm{pH}$ adjustment before and after heating. $J$ Dairy Res 55, 205-215

Stadhouders J (1982) Cooling and thermization as a means to extend the keeping quality of raw milk. Kiel Milchwirtsch Forschungsber 34, 19-28

Van Hooydonk ACM, de Koster PG, Boerrigter IJ (1987) The renneting properties of heated milk. Neth Milk Dairy J 41, 3-18

Wheelock JV, Kirk A (1974) The role of $\beta$-lactoglobulin in the primary phase of rennin action on heated casein micelles and heated milk. J Dairy Res 41, 367-372

Zittle CA, Thompson MP, Custer JH, Cerbulis J (1962) $\kappa$-casein - $\beta$-lactoglobulin interaction in solution when heated. J Dairy Sci 45, 807-810 